\title{
Feeding and Meat Quality of French Cattle Breeds in the Northern Trans-Ural
}

\author{
Olga Sheveleva \\ D.Sc. Department of Production and Processing \\ Technologies in Animal Farming, State Agricultural \\ University of Northern Trans-Ural, \\ Tuymen, Russia \\ olgasheveleva@mail.ru
}

\begin{abstract}
The article presents the results of scientific and farming-based experience in growing and fattening cattle of French meat breeds compared with the Hereford cattle breed. The study resulted in identifying the efficiency and expediency to use French meat breeds, such as charolais and obra, which were transferred to completely new environmental conditions when producing the high-quality beef. The bulls of the French breeds had an advantage in terms of body weight and the average daily growth over the Hereford cattle breed. When studying the indicators of meat productivity, it was found that the slaughter mass of calves of the Charolais breed was $597.0 \mathrm{~kg}$, about 569.0 $\mathrm{kg}$, which is more than this indicator in Hereford animals by $\mathbf{1 0 8 . 5}$ $\mathrm{kg} \mathrm{kg} 81.2 \mathrm{~kg}$, respectively. The animals of the Hereford breed had a smaller slaughter mass, but the highest slaughter-outpercentage that was obtained from them - 60.2. The Hereford breed of calves contains a higher percentage of fat compared with the other breeds. A higher content of fat in meat indicates an earlier maturity of this cattle breed.
\end{abstract}

Key words - breed, the Hereford, the Charolais, the Obrak, slaughter-out-percentage, body weight.

\section{INTRODUCTION}

Meat cattle breeding in Russia is characterized by a significant increase in animal herds, by using the innovative technologies and modern breeding methods, such as DNA diagnostics, and by using the best world breeds of cattle. Therefore, in beef production, the choice of breed is of great importance. In recent years, several breeds of cattle have been used in the country's livestock production. Therefore, it is important to find out the effectiveness of using the breed in beef production. [1-5].

In the Tyumen region, the four French cattle breeds for meat production are grown: Limousine, Charolais, Salers and Obrak. In addition, the Hereford cattle breed has been already used for a long time. Therefore, the study of meat productivity based on French meat breeds in conditions of the feedlot is relevant [6-7].

Some author studied the fattening and meat quality of cattle of various breeds, but there is no objective data on the fattening and meat quality of the cattle relating to the French meat breeds in comparison with the Hereford breed [8-11].

The purpose of the work is to conduct a breed test of French meat breeds in comparison with the Hereford in feedlot conditions.

\section{MethodOLOGY}

Before weaning, calves of beef breeds at the age of 210-220 days were kept according to the technology of beef cattle

\author{
Sergei Loginov \\ Department of Production and Processing Technologies in \\ Animal Farming, State Agricultural University of Northern \\ Trans-Ural, \\ Tuymen, Russia \\ serega230rus@mail.ru
}

breeding, in breeding reproducers of Tyumen Meat Company LLC.

After weaning, there have been formed the groups of meat breeds: 1 control group, formed from the Hereford breed calves, 2 and 3 groups - from the French meat breed calves. The calves of the breed Obrak entered the second group, the Charolais calves appeared in the 3 rd group. The number of animals in each group amounted to 15 heads. Further rearing and fattening took place in the feedlot conditions.

To study the dynamics of body weight, calves were weighed at the age of 9,12,15 and 18 months. Based on the data of body weight, the average daily growth in the different age periods was calculated for each group. At the age of 18 months, a control slaughter was conducted at the Yalutorovskiy meat processing plant that numbers three heads from each group. The control slaughter was carried out according to the method of the Academy of Agricultural Sciences, VISH, VNIMP (1997) [12]. During the control slaughter, a body weight, a hot carcass weight, a carcass yield, an internal fat mass, a slaughter-out-percentage were defined. To study the morphological composition of carcasses, deboning of half carcasses was carried out by using the meat industrial technology. The chemical analysis of minced meat was carried out at the State plant of the Tyumen agrochemical service.

The number-based data that we achieved within the experimental research were processed with the method of E.K. Merkurieva (1970) by using Windows XP operating system Microsoft Office Excel. The following symbols are used as conventions: * $\mathrm{P} 0.95 ; * * \mathrm{P} \leq 0,01 ; * * * \mathrm{P} \leq 0.001$ [13].

The calves were kept loosely, on a deep non-replaceable litter in a stationary room, with free access to walking and feeding lots. Watering was carried out from a group watering units with hot tray.

The conditions of keeping and feeding of all breeds animals were the same and corresponded to the technology used in beef cattle breeding. Feeding rations were developed taking into account the age and a body weight of calves to obtain the growth at the level of 1000-1100g. In a diet, the concentrates accounted for $33 \%$, stover -30 , succulent feed $-37 \%$.

\section{RESULTS}

Under the conditions of balanced feeding, a high growth energy of all groups animals there was noted. At the same time, there were noted the differences in an increase of a body weight among calves that was breed-depending factor. Data on a body weight are presented in table 1.

By the age of one year old, the calves of the second and the third groups were almost equal in a body weight value. Peers 
of the Hereford breed are significantly poorer in terms of this indicator. By the end of the experimental period, the highest body weight was among the calves of the Charolais breed. Since the age of 16 months, their body weight was $524.7 \mathrm{~kg}$, which is significantly more than the body weight of the Hereford calves by $75.5 \mathrm{~kg}(\mathrm{P} \geq 0.999)$. At the age of 18 months, the value of a body weight of the Charolais calves exceeded the peers of the Hereford breed by $102.8 \mathrm{~kg}$, (17.4\%), $(\mathrm{P} \geq 0.999)$.

The body weight of calves of the Obrak breed is more reliable than the Hereford bulls at the age of 16 months by 54.0 $\mathrm{kg}(11.1 \%)$, at 18 months by $76.0 \mathrm{~kg}(15.6 \%),(\mathrm{P} \geq 0.999)$. It should be noted that the greatest variability of a body weight is observed in the Hereford calves.

Thus, the calves of the French meat breeds surpass the peers of the Hereford breed in terms of a body weight.

TABLE I. DYNAMICS OF BODY WEIGHT, KG

\begin{tabular}{|c|c|c|c|c|c|c|}
\hline \multirow{2}{*}{$\begin{array}{c}\text { Anima } \\
\text { age, } \\
\text { month }\end{array}$} & \multicolumn{2}{|c|}{1} & \multicolumn{2}{c|}{$\mathbf{2}$} & \multicolumn{2}{c|}{3} \\
\cline { 2 - 7 } & $X \pm S_{x}$ & $\begin{array}{c}C v, \\
\%\end{array}$ & $X \pm S_{x}$ & $\begin{array}{c}C v, \\
\%\end{array}$ & $X \pm S_{x}$ & $\begin{array}{c}C v, \\
\%\end{array}$ \\
\hline $9-12$ & $\begin{array}{c}1047.7 \pm \\
74.4\end{array}$ & 29.6 & $961.7 \pm 28.0^{*}$ & 13.0 & 1220.9 & 14.3 \\
\hline $12-16$ & $\begin{array}{c}923.3 \pm 3 \\
7.8\end{array}$ & 17.0 & $934.8 \pm 28.8$ & 13.8 & 1109.4 & 16.2 \\
\hline $16-18$ & $\begin{array}{c}616.6 \pm 4 \\
7.6\end{array}$ & 31.9 & $\begin{array}{c}980.1 \pm 43.8^{*} \\
* *\end{array}$ & 20.0 & $\begin{array}{c}1070.0^{* *} \\
*\end{array}$ & 37.7 \\
\hline
\end{tabular}

An important indicator of the growth intensity is the average daily growth. During the experiment's time, the value of the average daily growth varied differently (table 2).

TABLE II. AVERAGE DAILY GROWTH OF MEAT BREED CALVES, G

\begin{tabular}{|c|c|c|c|c|c|c|}
\hline \multirow{2}{*}{$\begin{array}{c}\text { Anima } \\
\text { age, } \\
\text { month }\end{array}$} & \multicolumn{2}{|c|}{$\mathbf{1}$} & \multicolumn{2}{c|}{$\mathbf{2}$} & \multicolumn{2}{c|}{3} \\
\cline { 2 - 7 } & $X \pm S_{x}$ & $\begin{array}{c}C v, \\
\%\end{array}$ & $X \pm S_{x}$ & $\begin{array}{c}C v, \\
\%\end{array}$ & $X \pm S_{x}$ & $\begin{array}{c}C v, \\
\%\end{array}$ \\
\hline 9 & $\begin{array}{c}244.1 \\
\pm 8.0\end{array}$ & 14.7 & $\begin{array}{c}300.6 \pm 2.8^{*} \\
* *\end{array}$ & 4.27 & $278.3 \pm 3.1^{*}$ & 5.1 \\
\hline 12 & $\begin{array}{c}338.4 \\
\pm 6.5\end{array}$ & 8.5 & $\begin{array}{c}389.1 \pm 2.9^{*} \\
* *\end{array}$ & 3.38 & $\begin{array}{c}389.4 \pm 3.2^{*} \\
*\end{array}$ & 3.7 \\
\hline 16 & $\begin{array}{c}449.2 \\
\pm 6.3\end{array}$ & 6.2 & $\begin{array}{c}503.2 \pm 2.2^{*} \\
* *\end{array}$ & 1.96 & $\begin{array}{c}524.7 \pm 4.6^{*} \\
* *\end{array}$ & 3.9 \\
\hline 18 & $\begin{array}{c}486.2 \\
\pm 6.0\end{array}$ & 5.5 & $\begin{array}{c}562.0 \pm 2.7^{*} \\
* *\end{array}$ & 2.18 & $\begin{array}{c}589.0 \pm 5.0^{*} \\
* *\end{array}$ & 3.8 \\
\hline
\end{tabular}

During the period when animals were kept at the feedlot, the highest growths were observed in the Charolais calves, the value of the grtowth was 1070.0-1220.9g. High growths of the Charolais calves were shown from 9 to 12 months of their age. It is enough to note that in the final period of fattening their advantage amounted to $453.4 \mathrm{~g}(\mathrm{P} \geq 0.999)$.

Over the entire period of growing and fattening, the growth among the Charolais breed animals was $1003.2 \mathrm{~g}$, which is more than the Hereford peers by $155.7 \mathrm{~g}(18.4 \%)$. Calves exceeded the Hereford ones by $120.6 \mathrm{~g}(14.2 \%)$.

Thus, under the conditions of the intensive cultivation in feedlots, the calves of the French meat breeds surpassed the
Hereford ones in the growth intensity. When studying the characteristics of the growth of young meat breeds in the conditions of the Northern Trans-Urals, a different nature of a body weight changing and the average daily growth were identified. Between the breeds there have been noted the differences in the average daily growth.

One of the reserves to increase meat productivity and dietary protein is the rational use of the cattle breeds for beef production. Therefore, the rational rearing and fattening of the cattle, depending on breeding, can serve as an important step in solving a problem on how to increase beef production and improve its quality. In the study addressed the meat productivity, we tried to establish its dependence on a breed factor. To identify the dependence of the inheritance to a certain breed upon the meat productivity, a control slaughter was conducted among animals aged at 18 months. From all animals at slaughtering there were obtained heavy carcasses. The largest mass of carcasses was within the Charolais breed $346.5 \mathrm{~kg}$, the weight of carcasses from the Obrak breed was $320.0 \mathrm{~kg}$ and from the Hereford one $-277.3 \mathrm{~kg}$. The breed factor influenced the carcass output. Among the Charolais breed calves, the output of carcasses was $58.0 \%$, in the Obrak breed -56.2 , and in the Hereford calves $-56.8 \%$. The results of the control slaughtering are presented in table 3 .

TABLE III. SLAUGHTERING RESUlTS

\begin{tabular}{|c|c|c|c|c|c|c|}
\hline \multirow[b]{2}{*}{ Indicator } & \multicolumn{2}{|l|}{1} & \multicolumn{2}{|c|}{2} & \multicolumn{2}{|l|}{3} \\
\hline & $X \pm S_{x}$ & $\begin{array}{l}C v, \\
\%\end{array}$ & $X \pm S_{x}$ & $\begin{array}{c}C v, \\
\%\end{array}$ & $X \pm S_{x}$ & $\begin{array}{c}C v, \\
\%\end{array}$ \\
\hline $\begin{array}{c}\text { Pre- } \\
\text { slaughter } \\
\text { mass, kg }\end{array}$ & $\begin{array}{c}488.5 \pm 20 \\
.1\end{array}$ & 5,8 & $\begin{array}{c}569.7^{*} \pm 6 \\
.9\end{array}$ & 1.7 & $\begin{array}{c}597.0^{*} \pm 5 \\
.8\end{array}$ & 1.4 \\
\hline $\begin{array}{c}\text { Hot } \\
\text { carcass } \\
\text { mass, } \mathrm{kg}\end{array}$ & $\begin{array}{c}277.3 \pm 7 \\
6\end{array}$ & 3,9 & $\begin{array}{c}320.0 \pm 12 \\
.0\end{array}$ & 5.3 & $\begin{array}{c}346.3 \pm 5 \\
3\end{array}$ & 2.2 \\
\hline $\begin{array}{c}\text { Carcass } \\
\text { output, \% }\end{array}$ & 56.8 & & 56.2 & & 58.0 & \\
\hline $\begin{array}{c}\text { Internal } \\
\text { slaughter } \\
\text { fat mass, } \\
\mathrm{kg}\end{array}$ & $16.9 \pm 0.9$ & 7,7 & $10.0 \pm 0.7$ & 10.5 & $7.8 \pm 1.2$ & 27.3 \\
\hline $\begin{array}{c}\text { Deadweig } \\
\text { ht, kg }\end{array}$ & $\begin{array}{c}294,1 \pm 7 \\
3\end{array}$ & 3,5 & $\begin{array}{c}330,1 \pm 12 \\
, 7\end{array}$ & 5,5 & $\begin{array}{c}354,2 \pm 6 \\
3\end{array}$ & 2,5 \\
\hline $\begin{array}{l}\text { Carcass } \\
\text { yield, } \%\end{array}$ & 60.2 & & 57.9 & & 59.3 & \\
\hline
\end{tabular}

The largest mass of the internal fat there was in animals of the first group - $16.9 \mathrm{~kg}$, in the second group of calves it was less by $6.9 \mathrm{~kg}$ and in the third group it was less by $9.1 \mathrm{~kg}$. According to a slaughter weight indicator, the third-group calves exceeded the first group by $60.1 \mathrm{~kg}$, the second group by $26 \mathrm{~kg}$.

The most common indicator in meat productivity relating to cattle slaughtering is a slaughter yield. Despite the smaller slaughter weight, the animals of the first group had an advantage in terms of the slaughter yield $-60.2 \%$, the Charolais calves were ranked the second according to this indicator, and the Obrak breed had the lowest slaughter yield. Thus, given the fact that the Hereford breed calves at an early age have a more mature carcass it can be explained the high slaughter yield in this breed. 
This is confirmed by the amount of internal slaughter fat. When analyzing the results of the control slaughtering, it was found that the internal fat from the Hereford breed calves, who were slaughtered at the age of 18 months, was $16.9 \mathrm{~kg}$. This is more compared to the calves of the French breeds. In the Obrak calves the mass of fat was less by $6.9 \mathrm{~kg}$ and in the Charolais ones by $9.1 \mathrm{~kg}$. According to a slaughter mass, the third group calves exceeded the first one by $60.1 \mathrm{~kg}$, and the second one by 26kg. The animals of the Hereford breed had a smaller slaughter mass, but the highest slaughter yield that amounted to $60.2 \%$.

At the visual inspection, it was noted that the Hereford breed carcasses had more abundant fatty irrigation, both on the outside and on the inner side of carcass. Thus, such indicators of meat productivity as a slaughter weight, a slaughter fat weight and a slaughter yield depend on the breed factor.

The morphological composition of carcasses is presented in Table 4.

TABLE IV. MORPHOLOGICAL CARCASSES COMPOSITION

\begin{tabular}{|c|c|c|c|c|c|c|c|}
\hline \multirow{2}{*}{ Indicator } & \multicolumn{2}{|c|}{$\mathbf{1}$} & \multicolumn{2}{c|}{$\mathbf{2}$} & \multicolumn{2}{c|}{$\mathbf{3}$} \\
\cline { 3 - 8 } & & $X \pm S_{x}$ & $C v, \%$ & $X \pm S_{x}$ & $C v, \%$ & $X \pm S_{x}$ & $C v, \%$ \\
\hline \multirow{2}{*}{ Semi-carcass mass } & $137.8 \pm 3.6$ & 3.7 & $157.3 \pm 5.7$ & 5.1 & $175.4 \pm 3.4$ & 2.8 \\
\hline \multirow{2}{*}{ Flesh } & $\mathrm{kg}$ & $108.1 \pm 1.2$ & 1.6 & $117.8 \pm 3.1$ & 3.8 & $137.0 \pm 4.1$ & 4.3 \\
\cline { 2 - 8 } & $\%$ & 78.5 & & 74.9 & & 78.1 & \\
\hline \multirow{2}{*}{ Muscles } & $\mathrm{kg}$ & $103.5 \pm 0.9$ & 1.2 & $133.6 \pm 3.5$ & 3.7 & $165.0 \pm 5.0$ & 4.1 \\
\cline { 2 - 8 } & $\%$ & 75.1 & & 71.5 & & 75.9 & \\
\hline \multirow{2}{*}{ Fat } & $\mathrm{kg}$ & $4.6 \pm 0.4$ & 11.6 & $5.4 \pm 0.4$ & 10.6 & $4.0 \pm 0.4$ & 9.5 \\
\cline { 2 - 8 } & $\%$ & 3.4 & & 3.4 & & 2.3 & \\
\hline \multirow{2}{*}{ Bones } & $\mathrm{kg}$ & $27.0 \pm 3.0$ & 16.1 & $34.4 \pm 3.0$ & 12.3 & $32.9 \pm 0.4$ & 1.7 \\
\cline { 2 - 8 } & $\%$ & 19.6 & & 21.9 & & 18.7 & \\
\hline \multirow{2}{*}{ Gristles and chordas } & $\mathrm{kg}$ & $2.9 \pm 0.35$ & 16.8 & $21.6 \pm 0.54$ & 3.7 & $32.0 \pm 0.97$ & 4.5 \\
\cline { 2 - 8 } & $\%$ & 2.9 & & 4.9 & & 18.7 & \\
\hline
\end{tabular}

The morphological composition is determined by the ratio of muscle, fat, bones and connective tissues. Therefore, to obtain an objective assessment, 3 semi-carcasses were subjected to dissection. We set out the aim to define the dependence upon animals breed and the morphological composition of carcasses.

For consumer, the flesh part is of higher demand. The highest flesh output was obtained in animals of the Hereford breed $-78.5 \%$, in the Charolais calves -78.1 and in the Obrak ones $-74.9 \%$.

The greatest amount of bone tissue, both in absolute and relative terms, there was obtained from animals of the second group, where the number is $21.9 \%$.

The data analysis in terms of the morphological composition of carcasses indicates that the greatest amount of muscle tissue was obtained from animals of the Charolais breed that was 165 $\mathrm{kg}$. This is $62 \mathrm{~kg}$ more than from animal of the Hereford breed and $31.4 \mathrm{~kg}$ more than from the Obrak breed. Thus, during the slaughtering the animal of the Obrak breeds (at the age of 18 months), we obtained a greater amount of muscle tissue. The greatest amount of bone tissue there was received from the second group, the Obrak $-34.4 \mathrm{~kg}$, this is more than in the first group by $7.4 \mathrm{~kg}$ and in the third groups by $1.5 \mathrm{~kg}$.

The data obtained indicate about higher-quality composition of carcasses that are derived from the Charolais breed and about the large yield of edible parts.

When processing beef, a variety assortment of carcasses is of great importance, the data are given in table 5.

For animals of the Hereford breed, a higher yield of the highest sorts is attributable, the yield of the highest sort was
$27.8 \%$, while in absolute terms the amount of the highest sort meat was $26.8 \mathrm{~kg}$.

From semi- carcass of the Obrak breed there was received a smaller amount of meat of high quality in absolute and relative terms. According to meat yield regarding the first and second sorts the relative difference between the breeds is not significant, within a few percents.

TABLE V. VARIETY ASSORTMENT OF CARCESSES, $(\mathrm{X} \pm \mathrm{SX})$

\begin{tabular}{|c|c|c|c|c|c|c|}
\hline \multirow{2}{*}{ Group } & \multicolumn{2}{|c|}{ Highest } & \multicolumn{2}{c|}{ First } & \multicolumn{2}{c|}{ Second } \\
\cline { 2 - 7 } & $\mathrm{kg}$ & $\%$ & $\mathrm{~kg}$ & $\%$ & $\mathrm{~kg}$ & $\%$ \\
\hline 1 & $26.8 \pm 0.9$ & 27.8 & $42.1 \pm 0,9$ & 42.2 & $28.9 \pm 0,9$ & 30.0 \\
\hline 2 & $29.2 \pm 0.55$ & 17.9 & $51.8 \pm 1.39$ & 43.9 & $36.8 \pm 0.96$ & 38.2 \\
\hline 3 & $34.3 \pm 0.9$ & 30.0 & $57.8 \pm 1.5$ & 31.2 & $45.2 \pm 2.3$ & 32.9 \\
\hline
\end{tabular}

In the absolute terms, a greater amount of muscle tissue of the first and second sorts was obtained from the Obrak breed and the Charolais one, compared with the peers of the Hereford breed.

Our data are confirmed by the previous studies [14-16].

The chemical composition of meat is one of the most important and reliable methods to evaluate the meat productivity.

The chemical composition of animal meat was characterized by satisfied $k$, typical to a young stock of specialized meat cattle breeds. The chemical composition of the meat is given in table 6 .

Thus, analyzing the data on the chemical composition of meat, it should be noted that the calves of all breeds are characterized by the high quality, with the desired ratio of protein and fat. 
TABLE VI. CHEMICAL MEAT COMPOSITION, $\%$

\begin{tabular}{|c|c|c|c|c|c|c|}
\hline \multirow{2}{*}{ Indicator } & \multicolumn{2}{|c|}{$\mathbf{1}$} & \multicolumn{2}{c|}{$\mathbf{2}$} & \multicolumn{2}{c|}{$\mathbf{3}$} \\
\cline { 2 - 7 } & $X \pm S_{x}$ & $C v, \%$ & $X \pm S_{x}$ & $C v, \%$ & $X \pm S_{x}$ & $C v, \%$ \\
\hline Moisture & $74.2 \pm 0.8$ & 1.5 & $74.9 \pm 0.03$ & 2.1 & $75.4 \pm 0.2$ & 1.4 \\
\hline $\begin{array}{c}\text { Dry } \\
\text { substance }\end{array}$ & $25.8 \pm 0.8$ & 4.2 & $25.1 \pm 0.6$ & 3.6 & $24.6 \pm 0.2$ & 1.9 \\
\hline Fat, \% & $2.6 \pm 0.13$ & 7.3 & $2.35 \pm 0.03$ & 2.1 & $2.3 \pm 0.15$ & 9.2 \\
\hline $\begin{array}{c}\text { Protein, } \\
\%\end{array}$ & $22.1 \pm 0.7$ & 4.6 & $21.5 \pm 0.6$ & 3.9 & $21.4 \pm 0.3$ & 2.4 \\
\hline Ashes, \% & 1.1 & & 1.0 & & 0.9 & \\
\hline
\end{tabular}

\section{CONCLUSION}

1. The experiments that we had conducted allowed to reveal the efficacy and feasibility to use the animals of the French breeds as the Charolais and Obrak in production high-quality beef and for further development of the animal stockbreeding in the region.

2. Keeping the stocker cattle in the open feeding lot provided high body weight of calves belonging to the French breeds. The body weight of the Charolais amounts to $589.0 \mathrm{~kg}$, the Obrak $-562.0 \mathrm{~kg}$, that is more compared with the herd-mates of the Hereford by $102.8 \mathrm{~kg}(21.1 \%)$ and $75.8 \mathrm{~kg}(15.5 \%)$ $(\mathrm{P} \geq 0.999)$.

3. Animals of the French meat breeds possessed with the higher growth intensity. The highest daily gain was among the calves of the Charolais breed since 9 till 12 months old and amounted to $1220 \mathrm{~g}$, since 12 till 6 months old $-1109.4 \mathrm{~g}$; in the final stage of stocking it was $1070,0 \mathrm{~g}$. These values increased the corresponding values among the calves of the Hereford breed by $173.0 \quad(16.5 \%) \quad 174.2(18.8 \%)$ and $453.4(73.5 \%)$ $(\mathrm{P} \geq 0.999)$. the highest intensity in growth among the calves of the Obrak breed was observed in the final stage, when the value of daily gain since 16 till 18 months old was $980.1 \mathrm{~g}$., that exceeded the value in the Hereford breed by $363.4 \mathrm{~g}$. (58.9\%) $(\mathrm{P} \geq 0.999)$.

4. The calves' weight at slaughter in the Charolais breed amounted to $597.0 \mathrm{~kg}$, in the Obrak $-569 \mathrm{~kg}$, and these both values exceeded the value in the Hereford breed by $108.5 \mathrm{~kg}$ and $81.2 \mathrm{~kg}$ correspondingly. According to the value in the weight at slaughter, the calves of the third group exceeded the calves from the first group by $60.1 \mathrm{~kg}$, from the second group by $26 \mathrm{~kg}$. the animals, representatives of the Hereford breed had the minimum values of the weight at slaughter but the highest slaughter yield $-60.2 \%$.

5. The analysis of the data that we obtained through the carcasses morphological composition indicates that the greatest amount of muscle tissue was obtained from animals of the Charolais breed that was $165 \mathrm{~kg}$. This is $62 \mathrm{~kg}$ more than from animal of the Hereford breed and $31.4 \mathrm{~kg}$ more than from the Obrak breed. Thus, during the slaughtering the animal of the Obrak breeds (at the age of 18 months), we obtained a greater amount of muscle tissue. The greatest amount of bone tissue there was received from the second group, the Obrak $-34.4 \mathrm{~kg}$, this is more than in the first group by $7.4 \mathrm{~kg}$ and in the third groups by $1.5 \mathrm{~kg}$.

6. The amount of moisture and dry substance in meat that have been obtained from the different breeds, the difference is not significant. The Hereford calves meat contains a higher percentage of fat than other peers. A higher fat concentration in meat indicates about the earlier maturity of the Hereford cattle. The ashes concentration in meat of the different breeds also did not differ significantly.

\section{References}

[1] Kh.A. Amerkhanov, S.A. Miroshnikov, R.V. Kostyuk et al, "Draft concept of sustainable development of beef cattle in the Russian Federation until 2030", Bulletin of Beef Cattle Breeding, 2017, vol. 1 (97), pp. 7-11, retrieved from: http://kb.vniims.org.

[2] H. Gamarnik, O. Sheveleva, A. Durov, "Hereford cattle of Siberian breeding: monograph”, Tyumen State S.-H. Acad., GNU Sib. Research Institute of Livestock Ros. Acad. S.-H. sciences. Novosibirsk, Edition of "GNU SibNSHB of the Russian Agricultural Academy", vol. 201, 2010, p. 309.

[3] M. Chasovshchikova, O. Sheveleva, "Relationship between the genetic variants of kappa-casein and prolactin and the prod", Journal of Pharmaceutical Sciences and Research, vol. 9, no. 7, July 2017, pp. 10381044.

[4] O. Chernykh, A. Koshchaev, A. Lysenko, A. Shevchenko, A. Mishchenko, "Experience of diagnostics and containment of foot and mouth disease of cattle in Krasnodar region, Russia", Journal of Experimental Biology and Agricultural Sciences, vol. 5, 2017, pp. 786792.

[5] I.M. Dunin, "Breeding resources of specialized beef cattle - the basis of intensive beef production in Russia", Zootekhniya, 2018, no. 2, pp. 2-4.

[6] A.A. Bakharev, K.A. Fomintsev, "The influence of the class of parents on the productive quality of animal breed obrak in the conditions of the Tyumen region", AgroEkoInfo, 2018, no. 3.

[7] L.A. Glazunova, Yu.V. Glazunov, A.A. Ergashev, "Ecologicalepizootical situation on telasiosis among cattle in northern Ural region", Research Journal of Pharmaceutical, Biological and Chemical Sciences, 2018, vol. 9, no. 4, pp. 1687-1693.

[8] L.A. Lysenko, O.M. Sheveleva, "Growth, development and hematological indices of cattle of the Obrak breed of various generations in the conditions of the Northern Zauralye", Siberian Journal of Agricultural Science, 2008, no. 11, pp.23-27.

[9] A.A. Baharev, K.A. Fomintsev, "Exterior features of cattle breed obrak different body types in the conditions of the northern Zauralye", Proceedings of the Orenburg State Agrarian University, .2018, vol. 33 (71), pp. 216-218.

[10] A.A. Baharev, K.A. Fomintsev, "Exterior features of cattle breed obrak different body types in the conditions of the Northern Trans-Urals", News of Orenburg State University, 2018, vol. 33 (71), pp. 216-218.

[11] M. Tamarovsky, K. Amanzholov, T. Karymsakov et al, "Indicators of productivity and exterior of crossbred young stock from crossing local improved breeding stock with bulls of specialized meat breeds", Zootekhnik, no. 10, 2017, pp.9-12.

[12] A.F. Shevkhuzhev, M.B. Ulimbashev, "The effectiveness of the use of breed resources of cattle in the production of beef in the North Caucasus region", Dairy and beef cattle, no. 3, 2017, pp. 17-19.

[13] Guidelines for the study of meat productivity and meat quality of cattle. VIZH, VNIIMP. Dubrovitsy, 1977, pp. 38-40.

[14] E.K. Merkurieva, Biometrics in breeding and genetics of farm animals. Moscow: Kolos, 1970, p. 423.

[15] G.P. Legoshin, A.A. Alekseev, "The efficiency of breeding and using beef cows in terms of innovative technology", Dairy and Beef Cattle Breeding, no. 4, 2017, pp. 26-29.

[16] B.O. Inerbaev, A.I. Rykov, A.S. Durov, N.V. Borisov, I.A. Khramtsova, "A new technological solution for the meat farm for the production of dietary beef", Siberian Journal of Agricultural Science, 2016; vol. 5, pp. 41-47. 